\title{
Adapting the Risorgimento
}

\author{
Singer, Rita
}

\section{Women's Writing}

DOI:

10.1080/09699082.2016.1268342

Published: 01/01/2017

Peer reviewed version

Cyswllt i'r cyhoeddiad / Link to publication

Dyfyniad o'r fersiwn a gyhoeddwyd / Citation for published version (APA):

Singer, R. (2017). Adapting the Risorgimento: Ideas of Liberal Nationhood in L. M. Spooner's Country Landlords (1860). Women's Writing, 24(4), 466-481.

https://doi.org/10.1080/09699082.2016.1268342

\footnotetext{
Hawliau Cyffredinol / General rights

Copyright and moral rights for the publications made accessible in the public portal are retained by the authors and/or other copyright owners and it is a condition of accessing publications that users recognise and abide by the legal requirements associated with these rights.

- Users may download and print one copy of any publication from the public portal for the purpose of private study or research.

- You may not further distribute the material or use it for any profit-making activity or commercial gain

- You may freely distribute the URL identifying the publication in the public portal ?
}

Take down policy

If you believe that this document breaches copyright please contact us providing details, and we will remove access to the work immediately and investigate your claim. 


\section{Rita Singer}

\section{ADAPTING THE RISORGIMENTO: IDEAS OF LIBERAL NATIONHOOD IN L. M. SPOONER'S COUNTRY LANDLORDS (1860)}

For the Welsh middle classes, the 1850s were defined by a continuous struggle against English stereotypes that imagined Wales as a nation of promiscuous drunkards, incapable of self-rule and a burden for Britain. Whereas the Welsh press aggressively rebuffed such frequent accusations as soon as they sprung up, it took another ten years before Anglophone literature in Wales began to challenge Anglo-centric perceptions of the Welsh nation. Louisa Matilda Spooner was one of the first novelists who rejected the continued marginalization of Wales owing to its geographical distance from London, Britain's centre of art, commerce and politics. In her second work, Country Landlords (1860), she explores how Liberalism, philanthropy and Giuseppe Mazzini's republicanism form ideal prerequisites for Welsh squires. Under these circumstances, Welshness turns into a facet of Britishness because the ideal landlord in Wales fiercely defends his Welsh heritage and manages his property independently while remaining loyal to the union state.

Keywords: Victorian novel; Wales; Liberalism; national identity; biculturation

In 1860, Louisa Matilda Spooner published Country Landlords (1860), the second of her extant three novels. ${ }^{1}$ As one of the early contributions to a tradition of the Welsh novel in English, this Whiggish romance explores responsibilities of the Welsh nobility and gentry in the construction of a healthy national community at a time when, in the wider British context, Wales was regarded as little more than an administrative region of England. Chiefly the story follows the prolonged rivalry between two neighbouring estates near the coast of west Wales. The two young lovers, Anarawd Gwynne and the English-born Gertrude Fitzhammons, suffer under the antagonism between their (foster-)fathers who represent opposite poles of the Welsh squirearchy. On the one side there is the spendthrift Owen Herbert Gwynne who stems from a long line of Welsh noblemen; and on the other side, there is the retired sea captain Ricardo Lewis of part Italian descent who has only recently settled nearby. Eventually Captain Lewis is forced to flee Britain because Gertrude's remaining family discover that he had effectively kidnapped the girl after her parents' death and raised her like a daughter. Shortly after he and 
Gertrude reunite in Naples, Lewis is betrayed by an old enemy and he is killed whilst fighting on the barricades for a united Italian republic in 1848. After their fathers' deaths, Gertrude and Anarawd return to Wales for good and unite their inherited estates for the benefit of the entire nearby village as they marry and found their own Anglo-Welsh family.

Not much is known about the personal background of Louisa Matilda Spooner (1820 1886), except that she was the fifth of ten children of Elizabeth and James Spooner from Birmingham and spent most of her life in the Porthmadog area in Merionethshire, eventually living as a spinster together with her brother and his family. ${ }^{2}$ Her English and comfortably middle-class family background provides Spooner with a double vision of the largely Welshspeaking and Nonconformist community life in north-west Wales and influences the content and ideology of Country Landlords accordingly. Based on the descriptions of geographical landscape features, concrete place names and references to economy and infrastructure, the novel is set in Spooner's native, if slightly fictionalised Merionethshire of her youth and early maturity. Subsequently, Country Landlords reflects the favourable economic and political as well as language changes affecting the Welsh middle classes up to the 1860 s, while the vast majority of the Welsh peasant and working classes were subjected to "appalling living and working conditions". ${ }^{3}$ The social upward mobility of the comparatively small middle class in Wales expressed itself in a heightened civic confidence, as is evident, for example, in the heated public debate surrounding the Reports of the Commissioners of Inquiry into the State of Education in Wales (hereafter shortened to Reports) in 1847 in many weekly newspapers and periodicals published across Wales. ${ }^{4}$ The "Treachery of the Blue Books", as the Reports were soon renamed by their critics in Wales, dominated the columns of such weekly newspapers as The Principality: An Advocate of Civil, Commercial, and Religious Freedom (1847-50) from Haverfordwest (and later Cardiff) on the radical end of the political spectrum as well as the more moderate The Swansea and Glamorgan Herald and South Wales Free Press (1847-90). ${ }^{5}$ Despite the relative distance between the release of the Reports and Spooner's novels over a decade later, her literary construction of Welsh communities suggests the formation of a counter-discourse that particularly rejects the accusations issued against Welsh women for their supposed lewdness. ${ }^{6}$

In this heated climate of public debate in the periodical and news press, portrayals of Welsh-language culture increasingly found their way into other Anglophone domains, such as the novel, to whose popularity Spooner contributed in Wales as is evident by the Cambrian Journal's favourable review of her first novel, Gladys of Harlech, or: The Sacrifice (1858): 
Until the last few years we had no books of fiction, illustrative of Welsh manners and customs, that a genuine Cymro could for a moment tolerate [...]. [T]he true spirit of patriotism [...] penetrates [...] Gladys of Harlech, and gives life and vigour [...], which is refreshing to contemplate. ${ }^{7}$

In contrast to the enthusiastic reception of Gladys of Harlech in Wales, Geraldine Endsor Jewsbury, reviewer for The Athenaum, dismissed Spooner's second work as “a quasi Welsh story; but it suggests a suspicion that the writer is not a genuine Welsh woman, nor yet well up in points of national manners and customs. The characters do not smack of the Principality". ${ }^{8}$ Most likely it is Spooner's choice to set the story among the Welsh aristocracy during the Wars of the Roses that triggers this critique, as it inevitably tips the scale towards the portrayal of the most Anglicised section of Welsh society. ${ }^{9}$

Even though Endsor Jewsbury finds explicit examples of life in the Welsh hinterland missing, the social field constructed in Country Landlords clearly follows in the footsteps of the idealised and contemporary imagination of the gwerin, i.e. the comparatively egalitarian ordinary folk of Wales. ${ }^{10}$ This communal self-image emerged around the middle of the nineteenth century among the Anglo-Welsh middle classes who dominated the public discourse about Welsh nationhood in its relation to Britain. Owing to their earlier contact and identification with prestigious English-language institutions, such as universities, the Anglican Church and government administration, the middle classes had to bridge the gap between rival concepts of social order. As a means of diverting attention from their participation in the strictly horizontally divided class culture of England, they exaggerated the egalitarian component of the gwerin in order to confirm their rightful belonging into the Welsh national community with its imagined horizontal structures. In other words, the discourse about the national community in Wales gradually replaced the prototypical gwerin, i.e. the self-educated, Welsh-speaking and Nonconformist rural communities, with an English-speaking, urban middle-class that demonstrated their Welshness by conforming to the morals and sensibilities defined by the English Commissioners in their Reports. ${ }^{11}$ Spooner catches the problematic subtleties of the imagined egalitarianism as she subdivides her fictional villagers according to the distinct social groups recognised already by medieval Welsh law. These social groups used to be identified as the free bonheddwyr, "those who had bon or ancestry", and the unfree taeogion, the villeins; moreover, Country Landlords features members of the "alltud - the incomer[s] from beyond the boundaries of Wales". ${ }^{12}$ The increased social mobility of the British populace in the first half of the nineteenth century had 
brought these three classes closer together than previous centuries without erasing social rank entirely. Spooner's novel reflects these developments in the retained social stratification and illustrates the broadening definition of the imagined national community beyond the boundaries of the Welsh-speaking lower and peasant classes: her fictionalised gwerin simultaneously form an egalitarian community (Gemeinschaft) and a hierarchical society (Gesellschaft). ${ }^{13}$ Selecting then from a few romanticised, inoffensive peculiarities, Spooner thus endears Welsh Wales to an Anglophone readership. More importantly, however, Country Landlords embraces a mid-nineteenth century Liberal ideology as it engages with the question of inherited moral duty among the nobility and gentry for the country and its people while respecting the cultural distinctiveness of Wales at the Celtic periphery within the British union state. Consequently, the novel discards the dangers of political radicalism and republicanism in favour of Liberal ideals as the best form of governance in a multi-national constitutional monarchy.

\section{Narrating Liberalism: narrating a Welsh model village from an English point of view}

In the portrayal of the lives of the Welsh nobility and gentry, Country Landlords largely explores the idea of a national revival and employs a sentimental narrator to reach out to an English readership. ${ }^{14}$ Similar to Spooner's first novel, Gladys of Harlech, the narrator focuses on rivalries between noble families and touches on the cultural split between Wales and England. The narrator assumes a god-like control over time and space, leaping through the years and occasionally interrupting the action to provide a historical context for various settings, thus making the protagonists' motivations comprehensible to the reader: "Many events have since taken place, and are to be found in the records of the town of Angharad. These shall simply be touched upon in connection with the narrative, before proceeding further." $" 15$ As means of diverting attention from the story's fictional nature, the narrator also assumes the hindsight of the uninvolved historian: "To gloss over the trials sustained by the characters in the present narrative, and tint them with the couleur de rose, would be to paint an imperfect picture, to represent sunshine without shadows - the real would appear unreal."16 In combination with the historically verified failed rebellion in Italy in 1848, the pseudoreality of the narration is subsequently rooted within recent living memory of mid-nineteenth century Britain. 
The narrator propagates an account of the gwerin from above wherein it is the duty of the bonheddwyr to provide the necessary means for the improvement of living conditions of the disadvantaged taeogion. The social detachment from the lower classes is further corroborated in the portrayal of the inhabitants of Angharad who, despite a certain knack for poaching, are narrated as contented prisoners of their simple dwellings, living at the disposal of their social betters:

A small cottage at the instant came in sight, and, feeling painfully hungry, [the squire's son] stopped and entered the low doorway, in the hopes of obtaining a little refreshment. The inmate, a woman with a good-tempered smile, begged he would take a seat upon the settle, and she would in a few minutes make him a cup of tea, and give him the best of bread and butter. ${ }^{17}$

In the creation of this social dichotomy between action and reaction as a central force within the national community, the narrator follows a popular contemporary misconception of the Welsh peasantry as mired in deplorable living conditions and neglecting their livestock and farms if it were not for the altruistic intervention of the landed gentry. ${ }^{18}$ This fallacy not only betrays the narrator's othering of the wider populace in Wales, but also echoes Whig conceptualisations of British society and liberty for, as Jonathan Parry points out, "[t]he natural condition of a healthy society was for the propertied classes to rule". ${ }^{19}$ Only the concerted efforts of upper-class philanthropists advance the peasantry eventually and so help the national community to move forward as one:

No more filthy alleys inviting pestilence and disease; no more broken panes stuffed with threadbare stockings; no more dirty doorways crowded with pigs, fowls, and ragged urchins, were discernible. The children were at their schools, the shattered casements were removed, and windows of a much larger dimension were inserted in their place. $^{20}$

In line with mid-nineteenth century Liberal ideals, the narrator measures the principal reward for social activism not in economic increase of the landed gentry and nobility, but in an altruistic satisfaction gained from elevating the lower classes to a worthy life. Overall, the narrator shows little interest in a realistic portrayal of common rural life in Wales as only very few and far between scenes show any interaction between tenants and landlords, leave alone the daily life in the fictional village independent of the presence of the landed classes. In this 
position, the narrator betrays a disconnection from the social sphere of the Welsh peasantry. As R. J. Moore-Colyer points out

[...] the pursuit of high levels of profit was not [a Welsh farmer's] only consideration. To him, religious observance, bonds of kinship and standing in the community were of paramount significance and [...] the completion of a poem or essay for the local eisteddfod was every bit as important as producing abundant surpluses of wealth. ${ }^{21}$

Either through lack of awareness or deliberate obfuscation of these cultural particularities, the narrator of Country Landlords produces a Whiggish interpretation of the gwerin. While the hierarchy between landowners and tenants is at its most feudal, paradoxically, it results in the broadest attainable and, thus, egalitarian liberty which was founded on "the restraints and responsibilities of the rule of law" and "was not to be confused with licence". ${ }^{22}$ In other words, the quality of life among the common people of the land is entirely owed to the philanthropic undertakings of the ruling classes.

Roberto M. Dainotto argues that regionalism or "the importance of space" emerged as a way of reading modern society in the Anglophone novel in the British Isles during the nineteenth century, without constituting its own literary genre. ${ }^{23}$ However, Country Landlords with its mostly Welsh setting is not a regional novel. The fictional Angharad could easily be relocated to any rural area in mid-nineteenth Britain as the narrator first and foremost investigates social responsibility. By retreating behind a geographically un-marked terminology of local (self-)governance, the narrator extends the vision of an ideal society beyond the boundaries of the fictional Welsh estate and town to encompass the whole of reallife Britain:

[E]verything thrives when men of property fulfil their calling. There are no more bigoted objections to innovations among the people. The sturdy fellows at the plough begin to patronise new farm-implements, which at an earlier period they scornfully rejected. The farmers agree among themselves that what their young landlord recommended and approved must be beneficial. ${ }^{24}$

This imagination of an ideal union between "men of property" and "sturdy fellows at the plough" already presents an Anglicised revision of the gwerin, away from the socio-cultural markedness of Wales in comparison to an unmarked England as the kingdom's cultural and 
political default. Spooner's narrator appears to espouse "[ $t$ ]he emphasis of progressive thinkers in the $1850 \mathrm{~s}[\ldots]$ that the national community should be conceived in humane, crossclass, optimistic language" because the novel culminates in an idealistic description of a village recently roused from its former poverty under the leadership of a conscientious landlord. ${ }^{25}$

Despite the model character of this fictional Welsh village for any other village in the British Isles, social advance is persistently narrated as based on English virtues such as "[i]ndividual conscience, civic virtue, hard work, enterprise and respect for the law". ${ }^{26}$ Whilst the narrator aims at ameliorating the image of Wales as a semi-barbarous country in Englishlanguage fiction, in part this Anglo-centric view of Welsh barbarity is confirmed involuntarily. Any of the described innovations in Angharad have been imported from beyond the border by a mature, less unapologetically Welsh Anarawd and are implemented under his supervision. The narrator signals that Anarawd can only fulfil his role as the reformer because he has reached manhood because of his distance to Wales: "Since Anarawd left Wales, he had acquired a military air, without losing his former pleasant address, but his youthful look was gone." 27 The narrator praises Anarawd's eventual bicultural identity of Welsh feeling and English discipline, a blend which produces moral strength and makes him the perfect landowner as he balances Welsh patriotism with English dispassion for the benefit of his tenants. As Aaron points out, to the contemporary reader of Country Landlords, Anarawd's choice to settle down on the Welsh estate "is ultimately more progressive, more to do with the real 'cry of the present day' in Wales, than any imperial glory". ${ }^{28}$ It is in this respect that the narrator mirrors the emerging national confidence in Wales just over a decade after the Reports, suggesting to the non-Welsh readership an alternative community principle in which bonheddwyr and taeogion are defined by mutual support instead of class rivalry. In addition, Anarawd's and Gertrude's marriage constitutes a reversal of gendered imaginations of Wales as a feminine nation in opposition to the masculinised connotations regarding Englishness. ${ }^{29}$ Once he has surrendered the dangerously feminising fancy of antiquarian studies but retains a sober fondness for Wales, the Welsh Anarawd finds a perfect match in the English Gertude whose youthful bashfulness and determination has mellowed during her years of involuntary exile. Striking this balance, Spooner avoids narrating "a feminized (weak and subordinate) Wales [...] as 'married' to a masculine (strong and guiding) England". ${ }^{30}$

\section{Whigs and Tories: a novel in search for ideal local governance}


While Country Landlords clearly distinguishes between the Welsh and English populations as separate national communities with each their own languages, lifestyles and customs and traditions, they are united under one common government. Jane Aaron argues that "so overwhelming was the prestige of Great Britain as a modern, progressive and all-conquering imperial nation-state, that [...] these embryo nation-builders [...] were, in part, following English value systems". ${ }^{31}$ In the same way, Spooner devises Britishness as a supra-national identity that can only be contained in a union state made up of equal partners. However, this equality is problematic owing to the narrative's general Anglocentric outlook, not to mention the perpetuation of imperial Britain's undisputed supremacy over its colonial possessions, country and people alike, which is most prominently on display in the stereotyped portrayal of Lewis's Patois-speaking Black servant, Yarico. ${ }^{32}$

This does not mean that the novel rejects contemporary republicanism outright or embraces imperialism. To the contrary, "the glory of empire is consistently disparaged [...] particularly through the actions and sayings" of Captain Lewis. ${ }^{33}$ At the climax of the novel, he redeems himself by demonstrating his loyalty to the Risorgimento and their fight against the Papal state in May 1848. In essence, his death anachronistically reflects Whig ideology of the late 1850s which was directed "against the four faces of autocracy [...] -Austria, Russia, Napoleon III and the Pope". ${ }^{34}$ The stylisation of Ricardo Lewis as "noble gentleman" strictly follows Spooner's Liberal conceptualisation of the gwerin as "an optimistic term referring to the progress of the common folk of Wales coming to the fore in the 1840s and 1850s, after centuries of passivity and mute obedience to Welsh squire and parson". ${ }^{35}$ Lewis therefore sees himself as "the encourager of industry and the promoter of knowledge"; his part-Italian background and progressive ideology are ultimately expressed in the architecture of his new mansion in the style of the "Italian villa, except that it was much more massy and baroniallooking". ${ }^{36}$ In Lewis the civic duty of the responsible landlord merges with the democratic idealism of making education available for all, peasantry and women alike, going even so far as dismissing Gertrude's governess and overseeing her classical education himself. ${ }^{37}$ In that sense, Lewis's pursuits echo developments in Wales during the first half of the nineteenth century with the establishment of schools through private efforts, as was the case with Lady Charlotte Guest's exemplary provision of basic schooling in Dowlais. ${ }^{38}$ The literary philanthropist and school-founder Lewis may therefore be lacking a noble ancestry, but his social activism, which he finances through his successful economic endeavours, should in theory predestine him as ideal landlord: "I would have done a great deal for [the people of 
Angharad] if they would have let me, or rather if Mr. Gwynne had not put a clog to the wheel whenever I made the attempt." 39

Concerning his own family, however, Captain Lewis's loving but essentially tyrannical hold on Gertrude blots his otherwise noble character as he forbids her to marry Anarawd. This decision appears paradoxical, since Anarawd is of Welsh descent and has a great antiquarian interest in Welsh history. These qualities should naturally establish him as an ideal match for Gertrude, whose Englishness Lewis has tried to obliterate by raising her in Wales. However, he is irrationally convinced that Anarawd shares his father's abhorrence for all things Welsh and would thus corrupt the young woman: "If [Lewis] could only know [Anarawd's] character truly, he would be reconciled to him; they would be friends, and the country would benefit by their united exertions." ${ }^{\prime 4}$ It is against this type of intra-national antagonism then that Lewis's involvement in the Italian Risorgimento has to be re-evaluated. Before his death on the Naples barricades, he realises that preventing the marriage between Gertrude and Anarawd for fear of losing her to a rival squire mirrors the Italian situation:

Honour, Gertrude, I dare not sacrifice my honour. Having joined this anarchical society, so the enemies of freedom denominate all freedom of thought and deed-having sworn to support the cause of human right in this oppressed country, I dare not retract. [...] My last breath will be a prayer for your happiness. ${ }^{41}$

Spooner appropriates Giuseppe Mazzini’s Young Italy movement to comment on Welsh tribalism. Lewis eventually sees the error of his ways thanks to his involvement with the Risorgimento as he contributes to the unification of a fractioned Italian national community. In contrast to Ricardo Lewis, Owen Herbert Gwynne recalls the Irish steward Sir Kit Rackrent in Maria Edgeworth's Castle Rackrent (1800) for he embodies the archetype of a negligent absentee landlord who spends most of his time and money across the border in England. His indifference in home-affairs and lack of "interest in anything but selfindulgence" betray themselves in the appearance of the Bleddyn estate. ${ }^{42}$ The grounds and manor are truly Gothic as the ancestral home has fallen into disrepair; the estate externalises its owner's indifferent character as nature slowly creeps up on the man-made structures, "the glass door opening upon the gravel walk, its passage choked with sickly flowers, evergreens, and overgrown vegetation". ${ }^{43}$ On the few occasions that Gwynne does visit his Welsh home, he ridicules and terrorises his family. He is thus less of a father to Anarawd than Captain Lewis is to Gertrude, whom he has effectively abducted. Gwynne's fixation on England 
results in his complete division from his ancestral land and its people who, in return, show nothing but contempt for him: "I tell the truth, he was different to what he is now; he go among those strangers, and come back here, and think his countrymen can't do nothing," one of the Angharad locals complains. ${ }^{44}$

With the juxtaposition of the landlords Lewis and Gwynne, Spooner breaks with the tradition of configuring the gwerin along ethnic fault lines. Country Landlords reimagines the Welsh nation as a community defined by a shared set of values in which each social group fulfils their respective duty for the benefit of all. Jane Aaron argues that Lewis represents the ideal Welsh landlord as he has succeeded in the improvement of Angharad where Gwynne has failed. ${ }^{45}$ However, Lewis's unapologetic Welshness and Italian republicanism, which to the post-1850s British mind set carry dangerous notions of political radicalism, manifest themselves as antagonism towards Englishness and the crown which ultimately disqualifies him when put into the broader perspective of the British union state. ${ }^{46}$ Ultimately, Lewis's Anglophobia catches up with him when he is betrayed to his death by an English enemy, Lord Morlif, and Gwynne also fades away due to his prodigal lifestyle. ${ }^{47}$ Although Gwynne's Welshness is entirely inoffensive along cultural as well as political fault lines, his squandering lifestyle disqualifies him as a pillar of British society. Ultimately, it is Anarawd Gwynne who emerges as the perfect Welsh landlord because he successfully unites Welsh heart and English military discipline for the benefit of the local population.

\section{Bicultural protagonists: displaced heroes and kidnapped heroines}

The central characters in Spooner's entire body of work are uniformly set among the Welsh upper classes and their attitudes towards the peasantry are utilised as examples of good and bad landownership. The socio-political configuration and emplotment of the heroes and villains mark Country Landlords as a romance in which the historically verified Risorgimento links with the fictional protagonists' quests to improve the social conditions of the gwerin. ${ }^{48}$ The story unfolds in a diachronic manner, focussing on the structural transformation of Welsh society thanks to country estates which are ideologically rooted in a pre-modern Wales independent from an Anglocentric state. The conflict between Robert Lewis and Owen Herbert Gwynne links cultural identity with matters of class responsibility, examining "what

kind of leader, or landlord, [...] Wales need[s]". ${ }^{49}$ Anarawd and Gertrude are caught between the personal antagonism of their fathers who represent the two opposite poles of the Welsh 
squirearchy, namely the ancient aristocracy and the comparatively recent bourgeoisie. Although the eventual marital union between Gertrude and Anarawd serves as an entirely idealised example for the perfect Welsh bonheddwyr, Spooner presents this state of perfection as resulting from beneficial Anglicisation acting as a counterweight to expressions of unbridled Welshness. The resulting biculturation signifies a positive force because it unites positive traits of both language cultures, such as English formal learning and a Welsh sense of community, and exercises control over identified deficiencies, namely the abandon in English conspicuous consumption or Welsh nostalgia. This Anglo-Welsh power-play is carried out in the character development of Anarawd Gwynne.

Disenchanted by city life as well as feeling estranged from his father, Anarawd finds personal freedom in the location of his ancestral home: "I am charmed to be once more in Wales. I feel free again. I can now climb the hills [...] and enjoy life. I don't believe I could support another London season". ${ }^{50}$ Additionally, he orientates himself in terms of Wales's distant past in his antiquarian studies and the desire to learn the Welsh language. ${ }^{51}$ Anarawd's studies are encouraged by his mother, but she also urges him not to neglect his formal, read English schooling. ${ }^{52}$ Even though his antiquarian studies serve first and foremost as an escape mechanism that aligns him with a narrowly defined geographical location, they also allow Anarawd to establish a common ground with his tenants. To some measure, Anarawd thus turns into a fictional foil for the contemporary, English-born Lady Augusta Hall of Llanover (1802-1896), who was a great patron of the arts and antiquarian studies in Wales and held her personal pseudo-medieval court at Llanover Hall. ${ }^{53}$ Spooner may be criticised for stereotyping the majority of her peasant characters as stubborn layabouts, but her representation of relations between workers and paternalistic landowners is acutely rooted in the realities of life in north-west Wales during the first half of the nineteenth century:

$[W]$ here tenants were prepared to emulate systems adopted by their landlords, they would have been more likely to take notice of a Welsh-speaking resident squire whose interests were closer to their own than of an absentee proprietor whose instructions were executed by an English or Scottish agent. ${ }^{54}$

Additionally, landowners such as the Wynnes of Peniarth and the Nanneys of Gwynfryn continued the use of the Welsh language in their families in order to engage with their almost entirely Welsh-speaking tenants. ${ }^{55}$ However, before the fictional Anarawd can employ his cultural knowledge and language skills to improve the living conditions of his tenants, his role 
as responsible landowner also demands a higher education that provides him with an epistemic order for his unsystematic and, therefore, aimless antiquarian endeavours.

The balance between the two areas of knowledge follows the imagination of the ideal English gentleman who is not an expert in a narrowly defined field of study, but possesses a broad overview over a great number of subjects. In these instances, Anarawd resembles Ricardo Lewis; what places him above the rebellious Italo-Welsh captain, however, is his proven loyalty to the British union state by having fulfilled his duty in the English army at home and abroad. ${ }^{56}$ Analysing perceptions of place and time, Doreen Massey draws attention to ideologies that reject local rootedness "as a retreat from the (actually unavoidable) dynamic and change of "real life"" and define belonging as "romanticised escapism from the real business of the world" ${ }^{57}$ Likewise Dainotto stresses that "Critical Regionalism [...] believes [...], in a quite uncritical way, in the survival of past traditions and 'old roots' still available to a "contemporary culture",. ${ }^{58}$ Therefore, societal norms force the regionalist Anarawd to mature into a respectable British subject through his service in the army, although he takes up his commission only reluctantly. His tenure as army officer banishes him from his homeland for a considerable time as he has to travel the breadth and length of the British Empire. As a direct consequence, Anarawd learns to appreciate place as a process "conceptualised in terms of the social interactions" instead of an object, "motionless, frozen in time". ${ }^{59}$ When he eventually reunites with Gertrude, he has matured into the responsible landlord who no longer seeks escape in the past because he cannot face the present. To the contrary, he even continues Captain Lewis's social reform projects for Angharad.

Spooner further contests the image of a shameful Welsh femininity as propagated by the condescending, Anglocentric paternalism of the "Blue Books" as Gertrude's identification with Wales functions as a moral corrective to her English birth. Her emplacement tallies with the conventions of the romance genre and mirrors Anarawd's fate as Gertrude's idealised life on the fictional estate in Wales is juxtaposed with her trials and tribulations suffered in the very real settings of London and Naples during which she proves her constancy of character. ${ }^{60}$ Even before she falls out with her rediscovered relatives in England, she feels weary of the English nobility due to their antagonism towards the Welsh peasantry. ${ }^{61}$ The Anglican faith represents the only comforting form of Englishness in Gertrude's life and she attempts to share its uplifting strength with the gwerin by sponsoring a new church building for Angharad, much to Captain Lewis's surprise: 
"What! a church, Gertrude? A chapel would be far more appreciated. You forget what chapel-goers the Welsh are."

"Yes, but you know the reason: there are so few churches, and a sad dearth of energetic pastors. Were we to build more churches, and have some earnest, disinterested men, who would not neglect their parishes, I feel convinced the chapels would quickly diminish. [...]"62

Gertrude's attitude is decidedly Liberal Anglican as she criticises specifically those divisive socio-political dimensions within the Church of England that delineate "national religion in narrowly and divisively sectional terms". ${ }^{63}$ Gertrude thus insinuates that it is due to the Anglican clergy's disinterest in their parishioners' lives that Welsh chapels thrive. Spooner again draws from a great number of contemporary, discussions of and controversies about clerical care in Wales particularly where the Church of England is concerned. For example, Alfred Ollivant became the newly appointed bishop of Llandaff in 1850 despite being unable to converse with his parishioners in Welsh and remaining a resident of Cambridge instead of moving to his new bishopric. ${ }^{64}$ Gertrude's Liberalism directly derives from the idea of a nurturing and caring gentry for the benefit of all Britons. However, her intervention also presents a case of "internal colonialism" because she exerts the socio-cultural dominance of her Anglicised class over the Welsh villagers which then gives "English cultural forms superordinate status within the societies of the Celtic fringe". ${ }^{65}$ As Geraint H. Jenkins points out, by "stimulat[ing] literacy among the young and old" in Sunday school, organising eisteddfodau and hymn-singing festivals as well as encouraging sobriety, "Nonconformity encouraged upward social mobility". ${ }^{66}$ However, with her sponsorship of an Anglican church for Angharad, Gertrude dismisses any existing agency among the villagers:

They want arousing to a sense of their wretched condition. As long as they can fill their mouths with oat-cake and potatoes, they are contented. They are indeed in a half-savage state. We must civilize them. They must be educated. ${ }^{67}$

Owing to her hegemonic position in the social field, Gertrude privileges the institution closest to herself and against the demands and actual needs of the Welsh lower classes. As wellmeaning as Gertrude is towards the inhabitants of Angharad, she unwittingly follows in their othering as Celtic savages. Her privileged, Anglicised lifestyle thus forms the root of her judgement as she envisions the villagers as incapable children of nature who rely on the 
explicit guidance of their local squirearchy. On the one hand, the novel disparages British imperialism and the dominance of the English nobility. ${ }^{68}$ On the other hand, however, Spooner unintentionally employs the language of the English coloniser in Gertrude's verdict on the Welsh peasantry despite displaying a generally positive attitude towards the literary representation of the Cymry Cymraeg. Since Gertrude functions as a positively connoted interface between the English readership and the Welsh narrated subject, her actions and the ambiguous colonial language reflect mainstream attitudes towards social reform programmes in Wales after an English cultural model.

\section{Conclusion}

The literary representation of Welsh community life in Country Landlords derives from middle-class perceptions of the national community in the 1850s and 1860 s and indicates a beginning diversification in the imagination of the gwerin. The gwerin are re-invented as a national community defined by a shared set of values in which the different social groups fulfil their respective duties for the benefit of the community and, ultimately, the whole nation. Hailing from a family of English immigrants to Wales, Spooner's personal background provides the ideology on which the narration of protagonists from both sides of the Anglo-Welsh border is founded. Although Spooner's narrator distinctly remains apart from identifying with the Welsh nation on an ethnic basis, s/he engages in cultural translation and encourages Anglophone readers to readjust their view of Wales as a marginal region. With the two lovers, the English-born Gertrude Fitzhammons and the Welsh Anarawd Gwynne, Spooner breaks through the imagination of the Cymry as an ethnic group. Country Landlords engages in "Union Nationalism" by aligning itself with Wales as a culturally distinct region, but all the same presenting it "as a contributory nation to a greater Britain ruled by the English monarchy, rather than as a potentially sovereign nation justified in seeking its independence". ${ }^{69}$ Louisa Matilda Spooner offers a literary exploration of responsible guardianship over Wales and its people at a time when the Welsh national community faced institutionalised ridicule and denigration chiefly from the direction of England. By integrating (Italo-)Welsh aristocrats into rural communities at a great distance from London, Spooner affords Wales a more central position in historical as well as midVictorian Britain. 
Disclosure statement

No potential conflict of interest was reported by the author.

\section{Notes}

Rita Singer works as Research Officer for the AHRC-funded project "European Travellers to Wales, 1750-2010", jointly undertaken by Bangor University, University of Wales Centre for Advanced Welsh and Celtic Studies, Aberystwyth, and Swansea University. In 2013, she received her PhD from the British Studies Institute, Leipzig University for her thesis "Reinventing the Gwerin: Anglo-Welsh Identities in Fiction and Non-fiction, 1847-1914”. Her research focus is on Welsh writing in English in the public and the private sphere. Address: School of Modern Languages, Bangor University, LL57 2DG, UK. [email: mls206@bangor.ac.uk]

\footnotetext{
${ }^{1}$ Spooner may also be the author of a novel called Rich and Poor (1859), based on Charles J. Skeet's publishing announcement. See "Literary Notes of the Week," The Leader, 22 October 1859, p. 1181. However, no further information can be obtained about this novel and it may even well be the case that the announcement could refer to Country Landlords which was published the following year but by Spooner's new publisher, T. Cautley Newby, who also released her third known novel, The Welsh Heiress (1868).

${ }^{2}$ Jane Aaron identifies her dates of birth and death as 1821-1890. See Jane Aaron, Nineteenth-Century Women's Writing in Wales: Nation, Gender and Identity (2007; Cardiff: University of Wales Press, 2010), p 115. Other sources, however, deviate from those years. A detailed family tree for the Spooner family presents her life dates as 1820-1886. See D. H. W., "Family Tree of the Swinton Spooners," Ffestiniog Railway Magazine (1977), p.21. The date of death is further corroborated in a public notice placed in the London Gazette in 1887 by Spooner's solicitors, Bloxam and Son, who present the day of her death as 5 December 1886. See Bloxham and Son, "Louisa Matilda Spooner, Deceased," The London Gazette, 28 June 1887: 3516.

${ }^{3}$ Jones, Gareth Elwyn, and Gordon Wynne Roderick, "“Treason' and its Aftermath, 1847-1870", A History of Education in Wales, by Gareth Elwyn Jones and Gordon Wynne Roderick (Cardiff: University of Wales Press 2003), pp. 56-74 (57).

${ }^{4}$ As Gwyneth Tyson Roberts points out, prior to the publication of the Reports, the Welsh "were prepared to hear that they were poorly educated; they had not expected to be told that they were drunken, dirty, superstitious and sexually promiscuous liars and cheats". See Gwyneth Tyson Roberts, The Language of the Blue Books: Wales and Colonial Prejudice (1998; Cardiff: University of Wales Press, 2011), p. 209. The Commissioners' skewed view of Welsh community life reproduced Anglo-centric hetero-stereotypes of the population in Wales as an ethnically inferior Celtic nation with next to no regard for Christian morality, which inevitably contributed to the high levels of poverty and childbirth out of wedlock. The Commissioners traced these failings back to the still widely spoken Welsh language and Nonconformism: "Above all was the want of chastity in the women which resulted from the practice of 'bundling' and much increased by night prayer meetings and the 'intercourse which ensues in returning home"'. Therefore, the Reports arrived at the conclusion that, as long as all three fields of influence remained unchecked, Wales would remain an ungovernable and ignorant region and a burden to Britain in general and to England especially. See Ieuan Gwynedd Jones, Mid-Victorian Wales: The Observers and the Observed (Cardiff, University of Wales Press, 1992), pp. 143, 137.
} 
${ }_{6}^{5}$ Jones and Roderick, p. 60.

${ }^{6}$ Kirsti Bohata, Postcolonialism Revisited: Writing Wales in English (Cardiff: University of Wales Press, 2004), p. 62.

7 "Reviews," The Cambrian Journal (1858), pp. 158-160 (158-9). See: [Louisa Matilda Spooner], Gladys of

Harlech; or, The Sacrifice. 3 vols. (London: Charles J. Skeet, 1858)

${ }^{8}$ [Geraldine Endsor Jewsbury], "New Novels", The Athenaeum, 7 July1860: 15.

${ }^{9}$ See Philip Jenkins, A History of Modern Wales, 1536-1990 (1992; London and New York: Routledge, 1997), p. 61.

${ }^{10}$ Susan Pitchford has highlighted the general difficulty of translating the Welsh gwerin into English and further stresses that in nineteenth-century Wales the term evolved from a more rural conceputalisation of the national community to include a much wider demography: "The word has no English equivalent ... though "common folk' is a fair translation. The gwerin acquired a symbolic significance as an expression of Welsh national identity during the late 19th century; originally a rural type, industrial workers were included as a kind of extended family. The term evokes a noble if simple people forming a classless and unified community." See Susan Pitchford, Identity Tourism: Imaging and Imagining the Nation (Bingley: Emerald, 2008), p. 24.

${ }^{11}$ Gwyn A. Williams, When Was Wales?: A History of the Welsh (1985; London: Penguin, 1991), p. 237.

${ }^{12}$ John Davies, A History of Wales, 5th ed. (1990; London: Penguin, 2007), pp. 87, 88.

${ }^{13}$ Ferdinand Tönnies differentiates between Gesellschaft (society) as oriented towards individualism and negotiation and Gemeinschaft (community) as oriented towards community and reciprocity. See: Michael Opielka, Gemeinschaft: Soziologie nach Hegel und Parsons, 2nd revised ed. (2004; Wiesbaden: VS Verlag für Sozialwissenschaften, 2006), pp. 29, 33.

${ }^{14}$ Aaron, p. 116.

${ }^{15}$ S[pooner], L[ouisa] M[atilda]. Country Landlords, 3 vols. (London: T. C. Newby,1860), vol. 1, p. 61. Hereafter Country Landlords is abreviated to $C L$.

${ }^{16}$ S[pooner], $C L$, vol. 3, p. 1.

${ }^{17}$ Emphasis added; Spooner, $C L$, vol. 1, p. 219.

${ }^{18}$ R. J. Moore-Colyer, "Landowners, Farmers and Language in the Nineteenth Century", The Welsh Language and Its Social Domains, 1801-1911, ed. Geraint H. Jenkins (Cardiff: University of Wales Press, 2000), pp. 101$30(107-8)$.

${ }^{19}$ Jonathan Parry, The Politics of Patriotism: English Librealism, National Identity and Europe, 1830-1886 (Cambridge: Cambridge University Press 2006), p. 51.

${ }^{20}$ S[pooner], $C L$, vol. 3, p. 327.

${ }^{21}$ Moore-Colyer, p. 109.

${ }^{22}$ Parry, pp. 49, 50.

${ }^{23}$ Roberto M. Dainotto, Place in Literature: Regions, Cultures, Communities (Ithaca and London: Cornell University Press, 2000), pp. 28, 30.

${ }^{24}$ S[pooner], $C L$, vol. 3, p. 328.

${ }^{25}$ Parry, p. 99.

${ }^{26}$ Parry, p. 62.

${ }^{27}$ S[pooner], $C L$, vol. 3, p. 81.

${ }^{28}$ Aaron, p. 117.

${ }^{29}$ Bohata, p. 72.

${ }^{30}$ Bohata, p. 72.

${ }^{31}$ Aaron, p. 80.

${ }^{32}$ Yarico's civic status remains ambivalent throughout the novel. On the one hand, she is a greatly respected member of Lewis's domestic staff and Gertrude depends on her greatly for emotional support. See S[pooner], $C L$, vol. 2, pp. 28, 122-5. On the other hand, neither Yarico nor Gertrude correct Lady Strangford as she calls Yarico a slave as late as the 1840s; this constitutes an anachronism in light of the British Slavery Abolition Act of 1833. See S[pooner], $C L$, vol. 1, pp. 49, 52.

${ }^{33}$ Aaron, p. 117.

${ }^{34}$ Parry, p. 223.

${ }^{35}$ Prys Morgan, „The Gwerin of Wales-Myth and Reality“, The Welsh and Their Country: Selected Readings in the Social Sciences, ed. Ian Hume and W. T. R. Pryce (Llandysul: Gomer, 1986), pp. 134-52 (135).

${ }^{36}$ S[pooner], $C L$, vol. 1, pp. 63, 64.

${ }^{37}$ S[pooner], $C L$, vol. 1, pp. 66-7, 103.

${ }^{38}$ G. E. Jones, pp. 60-1; Moore-Colyer, p. 120.

${ }^{39}$ S[pooner], $C L$, vol. 2, p. 236.

${ }^{40}$ S[pooner], $C L$, vol. 2, p. 237.

${ }^{41}$ S[pooner], $C L$, vol. 3, p. 132.

${ }^{42}$ S[pooner], $C L$, vol. 1, p. 62. 
${ }^{43}$ S[pooner], $C L$, vol. 1, pp. 40, 41. Spooner's fictional landscapes generally appear to exist in a symbiotic relationship with their respective owners as a similar fate awaits Captain Lewis's estate after his flight from Britain into Italian exile. See S[pooner], $C L$, vol. 3, p. 88: "[T] he shutters were either wholly or partially closed, and the creepers hung loose from the sides of the house, falling in ungraceful festoons. [...] Grass and weeds thriving in the gravel, dead leaves and boughs strewed from end to end in profusion. [...] What a wilderness! what dreariness! Poor Lewis!"

${ }^{44}$ S[pooner], $C L$, vol. 1, p. 17

${ }^{45}$ Aaron, p. 118.

${ }^{46}$ Parry, p. 233.

${ }^{47}$ S[pooner], $C L$, vol. 3, pp. 138-9; vol. 2, p. 72.

${ }^{48}$ Hayden White, Metahistory: The Historical Imagination in Nineteenth-Century Europe, 11th ed. (Baltimore, Johns Hopkins University Press, 1978), pp. 8, 10.

${ }^{49}$ Aaron, p. 116.

${ }^{50}$ S[pooner], $C L$, vol. 1, p. 107.

${ }^{51}$ S[pooner], $C L$, vol. 1, pp. 52-3.

${ }^{52}$ S[pooner], $C L$, vol. 1, pp. 53-4.

${ }^{53}$ Davies, 376; "Meeting of Welsh Harpers at Llanover," The Aberystwyth Times, Cardiganshire Chronicle, and Merionethshire News, 23 October 1869: 3.

${ }^{54}$ Moore-Colyer, 111. Interestingly, Country Landlords opens with a night-time scene in a guest house in Angharad with the arrival of a Scottish farming agent acting on behalf of the disinterested, absentee landlord Owen Herbert Gwynne who is instantly rebuffed by a Welsh farmer for his compliance! See S[pooner], $C L$, vol. 1 , pp. 7-8, 16-7.

${ }_{55}^{5}$ Moore-Colyer, p. 119.

${ }^{56}$ S[pooner], $C L$, vol. 2, pp. 198-200.

${ }^{57}$ Doreen Massey, “A Global Sense of Place”, Marxism Today (1991): 24-29 (26).

${ }^{58}$ Dainotto, p. 17.

${ }^{59}$ Massey, p. 29.

${ }^{60}$ Emplacement "constitutes a character's relational position in a symbolically charged geography" and "determines the power dynamics between individual characters and their communities". See Rita Singer, "Bicultural Geographies: Narrating Anglo-Welsh Identities in the Novels of Allen Raine", International Journal of Welsh Writing in English 3 (2015): 102-22 (102-3). Franco Moretti, Atlas of the European Novel, 1800-1900. (1997; London: Verso, 2009), p. 18.

${ }^{61}$ S[pooner], $C L$, vol. 1, pp. 267, 280.

${ }^{62}$ Emphasis added; Spooner, $C L$, vol. 2, pp. 263-4.

${ }^{63}$ Parry, p. 96.

${ }^{64}$ Roger L. Brown, "In Pursuit of a Welsh Episcopate", Religion and National Identity: Wales and Scotland, c. 1700-2000, edited by Robert Pope (Cardiff: University of Wales Press, 2001), pp. 84-102 (84-5).

${ }^{65}$ Michael Hechter, Internal Colonialism: The Celtic Fringe in British National Development; with a New Introduction and Appendix by the Author (1975; New Brunswick: Transaction Publishers, 1999), p. 109.

${ }^{66}$ Geraint H. Jenkins, A Concise History of Wales (Cambridge: Cambridge University Press, 2007), pp. 208, 210.

${ }^{67}$ S[pooner], $C L$, vol. 2, p. 270.

${ }^{68}$ Aaron, p. 117.

${ }^{69}$ Thomas Phillips quoted in Aaron, p. 72. See Chris Williams, "Problematizing Wales: An Exploration in Historiography and Postcoloniality", Postcolonial Wales, ed. Jane Aaron and Chris Williams (Cardiff: University of Wales Press, 2005), pp. 3-22 (6). 